\title{
Hubungan Kebiasaan Mencuci Tangan dan Memotong Kuku dengan Kejadian Giardiasis Asimtomatik
}

\author{
Mentari Artika ${ }^{1}$, Nurhayati ${ }^{2}$, Yustini Alioes ${ }^{3}$
}

\begin{abstract}
Abstrak
Infeksi protozoa intestinal masih merupakan masalah kesehatan di negara tropis dan negara berkembang. Protozoa intestinal yang tersering bagi manusia adalah Giardia lamblia. Tujuan penelitian ini adalah menentukan hubungan kebiasaan mencuci tangan dan memotong kuku terhadap kejadian giardiasis asimtomatik pada murid SDN 14 Olo Kecamatan Padang Barat Kota Padang. Penelitian ini dilakukan secara cross sectional dari Februari sampai September 2014 dengan 63 subjek penelitian. Kebiasaan mencuci tangan dinilai dengan kuesioner sedangkan kebiasaan memotong kuku dinilai dengan pengamatan. Pemeriksaan tinja dilakukan di laboratorium Parasitologi Fakultas Kedokteran Universitas Andalas untuk melihat kista Giardia lamblia. Hasil penelitian dilakukan uji chi-square dengan nilai kemaknaan <0,05. Hasil penelitian ini menunjukkan bahwa 14 (22,2\%) murid terinfeksi Giardia lamblia. Kebiasaan mencuci tangan murid SDN 14 Olo sebanyak 20 (31,7\%) murid dikategorikan buruk dan sebanyak 26 $(41,3 \%)$ murid mempunyai kebiasaan memotong kuku yang buruk. Hasil penelitian ini menunjukkan bahwa ada hubungan antara kebiasaan mencuci tangan dengan kejadian giardiasis asimtomatik pada murid SDN 14 Olo Kecamatan Padang Barat Kota Padang $(p<0,001)$ dan tidak ada hubungan antara kebiasaan memotong kuku dengan kejadian giardiasis asimtomatik pada murid SDN 14 Olo Kecamatan Padang Barat Kota Padang $(p<0,945)$.
\end{abstract}

Kata kunci: infeksi giardia lamblia, mencuci tangan, memotong kuku

\begin{abstract}
Intestinal protozoa infection is still one of the public health problems which still be found, especially in tropics and poor rural communities world wide. The most prevalence of intestinal protozoa is Giardia lamblia. The objective of this research was to determine the relation between the habit of hand washing and cutting nails on the incidence of asymptomatic giardiasis on students of SDN 14 Olo Kecamatan Padang Barat, Kota Padang. The research used cross sectional method, it held from February to September 2014 with 63 research subjects. Hand washing habits measured by questionnaire and habits of cutting nail measured by observation. Fecal examination conducted in the laboratory of Parasitology, Faculty of Medicine Andalas University, to see Giardia lamblia cysts. Chi square was used for analysis with $<0.05$ degree of reliance. The results showed that 14 (22.2\%) students are infected with Giardia lamblia students. Hand washing habits of students in SDN 14 Olo is 20 (31.7\%) students categorized as poor and 26 (41.3\%) students have a bad habit of cutting nails. The results showed that there was relation between the habits of hand washing habits with the incidence of asymptomatic giardiasis on students of SDN 14 Olo Kecamatan Padang Barat, Kota Padang $(p<0,001)$, and there was not relation beetwen nail cutting with the incidence of asymptomatic giardiasis on students of SDN 14 Olo Kecamatan Padang Barat, Kota Padang $(p<0,94)$.
\end{abstract}

Keywords: giardia lamblia infection, hand washing, cutting nails

Affiliasi penulis: 1. Prodi Profesi Dokter FK Unand (Fakultas Kedokteran Universitas Andalas Padang), 2. Bagian Parasitologi FK Unand, 3. Bagian Biokimia FK.Unand.

Korespondensi: Mentari Artika, Email: mentari_artika@yahoo.com, Telp: 085271172442

\section{PENDAHULUAN}

Giardiasis merupakan salah satu infeksi pada saluran cerna yang disebabkan oleh protozoa patogen yaitu Giardia lamblia. Jenis protozoa ini 
ditemukan pada saluran gastrointestinal berbagai macam mamalia termasuk manusia. ${ }^{1}$

Giardia lamblia menginfeksi manusia dengan menelan kista matang yang terjadi secara langsung maupun tidak langsung. Penularan secara langsung terjadi antara individu yang terinfeksi dengan individu yang tidak terinfeksi seperti melalui tangan ke mulut dan secara fecal-oral. Transmisi secara ano-oral terjadi pada orang yang melakukan oral-anal seks baik pada homoseksual maupun heteroseksual. ${ }^{2}$ Penularan secara tidak langsung melalui air yang mengandung kista Giardia Lamblia akibat kontaminasi oleh tinja manusia maupun hewan, makanan yang terkontaminasi akibat pengaruh lingkungan dengan higiene rendah. Giardiasis juga dapat terjadi melalui transmisi dari hewan ke manusia, seperti tikus, domba, sapi, anjing dan burung yang terinfeksi oleh Giardia lamblia, serta wisatawan yang mengunjungi beberapa area yang endemik atau area dengan higiene rendah. ${ }^{3}$

Manifestasi klinis yang disebabkan oleh giardiasis sangat bervariasi dan dapat berbeda pada penderitanya, mulai dari asimtomatik, diare akut hingga diare kronik, penurunan berat badan, steatore dan malabsorbsi. Manifestasi klinis ini dipengaruhi berbagai faktor seperti jumlah kista yang tertelan, lamanya infeksi, faktor hospes seperti status imun, status nutrisi, usia dan parasitnya sendiri. ${ }^{4}$

Giardia lamblia merupakan penyebab tersering infeksi protozoa pada saluran cerna manusia dan paling banyak ditemukan di negara berkembang. Negara Indonesia merupakan salah satu negara berkembang yang memiliki prevalensi giardiasis secara umum berkisar $3,67 \%$ dan prevalensi giardiasisdi Indonesia pada tahun 2004 adalah sebesar 3,62\%. ${ }^{5,6}$

Provinsi Sumatera Barat khususnya di Kota Padang telah dilakukan penelitian terhadap 66 orang anak binaan Rumah Singgah Amanah Kelurahan Rimbo Kaluang, Kecamatan Padang Barat Kota Padang. Berdasarkan hasil penelitian tersebut didapatkan distribusi frekuensi protozoa intestinal sebesar $40,91 \%$ dan berdasarkan jenis spesies, frekuensi infeksi tertinggi disebabkan oleh Giardia lamblia yaitu $37,88 \%{ }^{8}$
Penelitian ini bertujuan untuk menentukan hubungan kebiasaan mencuci tangan dan memotong kuku dengan kejadian giardiasis asimtomatik pada murid SDN 14 Olo Kecamatan Padang Barat Kota Padang.

\section{METODE}

Penelitian ini menggunakan desain cross sectional analitik yang dilaksanakan pada Februari Oktober 2014. Penelitian ini dilakukan di SDN 14 Olo Kecamatan Padang Barat Kota Padang, sedangkan pemeriksaan tinja dilakukan di laboratorium Parasitologi Fakultas Kedokteran Universitas Andalas. Pengambilan sampel dengan menggunakan teknik total sampling dengan jumlah populasi 107 murid, sedangkan jumlah sampel penelitian adalah 63 murid yang memenuhi kriteria inklusi. Untuk mengetahui angka kejadian giardiasis dilakukan melalui pemeriksaan tinja dengan pewarnaan langsung, yaitu dengan pewarnaan eosin $2 \%$ sedangkan kebiasaan mencuci tangan dilakukan dengan menggunakan kuesioner. Untuk kebiasaan memotong kuku dengan melakukan observasi yang dilakukan sebanyak 3 kali selama 3 minggu berturut-turut. Data yang terkumpul selanjutnya dianalisis dengan analisis univariat untuk memberikan gambaran karakteristik masing-masing variabel yang diteliti dan analisis bivariat untuk membuktikan ada atau tidaknya hubungan antara variabel.

\section{HASIL}

Tabel 1. Distribusi frekuensi kejadian giardiasis asimtomatik pada murid SD N 14 Olo Kecamatan Padang Barat, Kota Padang.

\begin{tabular}{ccc}
\hline Giardiasis & Frekuensi & $\%$ \\
\hline Positif & 14 & 22,2 \\
\hline Negatif & 49 & 31,7 \\
\hline Total & 63 & 100 \\
\hline
\end{tabular}

Pada Tabel 1, dapat dilihat persentase anak yang terinfeksi Giardia lamblia sebesar 22,2\%. 
Tabel 2. Distribusi frekuensi kebiasaan mencuci tangan pada murid SDN 14 Olo Kecamatan Padang Barat, Kota Padang.

\begin{tabular}{ccc}
\hline Kebiasaan Mencuci Tangan & Frekuensi & $\%$ \\
\hline Baik & 43 & 68,3 \\
\hline Buruk & 20 & 31,7 \\
\hline Total & 63 & 100 \\
\hline
\end{tabular}

Pada Tabel 2 dapat dilihat bahwa 68,3\% murid mempunyai kebiasaan mencuci tangan yang baik.

Tabel 3. Distribusi frekuensi kebiasaan memotong kuku pada murid SD N 14 Olo Kecamatan Padang Barat, Kota Padang.

\begin{tabular}{lll}
\hline Kebiasaan Memotong Kuku & Frekuensi & $\%$ \\
\hline Baik & 37 & 58,7 \\
\hline Buruk & 26 & 41,3 \\
\hline Total & 63 & 100 \\
\hline
\end{tabular}

Tabel 3 memperlihatkan bahwa $58,7 \%$ murid mempunyai kebiasaan memotong kuku yang baik.

Tabel 4. Hubungan kebiasaan mencuci tangan dengan kejadian giardiasis asimtomatik pada murid SD N 14 Olo Kecamatan Padang Barat, Kota Padang.

\begin{tabular}{ccccccc}
\hline \multirow{2}{*}{$\begin{array}{c}\text { Mebiasaan } \\
\text { Mencuci }\end{array}$} & \multicolumn{4}{c}{ Giardiasis } & \multicolumn{2}{c}{ Total } \\
\cline { 2 - 5 } Tangan & Positif & \multicolumn{2}{c}{ Negatif } & & \\
\cline { 2 - 6 } & $\mathbf{f}$ & $\%$ & $\mathbf{f}$ & $\%$ & $\mathbf{f}$ & $\%$ \\
\hline Buruk & 10 & 50 & 10 & 50 & 20 & 100 \\
Baik & 4 & 9,3 & 39 & 90,7 & 43 & 100 \\
\hline & & & & \multicolumn{4}{c}{ Nilai $p<0,001$} \\
\hline
\end{tabular}

Pada Tabel 4, hasil yang diperoleh dihubungkan dengan variabel lain menggunakan uji chi-square. Proporsi responden yang mengalami giardiasis asimtomatik lebih banyak pada kebiasaan mencuci tangan yang buruk dibandingkan dengan yang baik $(50 \%: 9,3 \%)$. Secara statistik perbedaan ini bermakna $(p<0,05)$, dapat disimpulkan bahwa ada hubungan yang bermakna antara kebiasaan mencuci tangan dengan kejadian giardiasis asimtomatik pada murid SDN 14 Olo Kecamatan Padang Barat Kota Padang.
Tabel 5. Hubungan kebiasaan memotong kuku dengan kejadian giardiasis asimtomatik pada murid SD N 14 Olo Kecamatan Padang Barat, Kota Padang.

\begin{tabular}{ccccccc}
\hline \multirow{2}{*}{$\begin{array}{c}\text { Kebiasaan } \\
\text { Kuku }\end{array}$} & \multicolumn{4}{c}{ Giardiasis } & \multirow{2}{*}{ Total } \\
\cline { 2 - 5 } & \multicolumn{2}{c}{ Positif } & \multicolumn{2}{c}{ Negatif } & & \\
\cline { 2 - 6 } & $\mathbf{f}$ & $\%$ & $\mathbf{f}$ & $\%$ & $\mathbf{f}$ & $\%$ \\
\hline Buruk & 9 & 34,6 & 17 & 64,5 & 26 & 100 \\
Baik & 5 & 13,5 & 32 & 86,5 & 37 & 100 \\
\hline & & & & & Nilai $p<0,94$ \\
\hline
\end{tabular}

Pada Tabel 5, hasil yang diperoleh dihubungkan dengan variabel lain menggunakan uji chi-square. Proporsi responden yang mengalami giardiasis asimtomatik lebih banyak pada kebiasaan memotong kuku yang buruk dibandingkan dengan yang baik $(34,6 \%: 13,5 \%)$. Secara statistik perbedaan ini tidak bermakna $(p>0,05)$, sehingga dapat disimpulkan bahwa tidak ada hubungan yang bermakna antara kebiasasan memotong kuku dengan kejadian giardiasis asimtomatik pada murid SDN 14 Kecamatan Padang Barat, Kota Padang.

\section{PEMBAHASAN}

Distribusi Frekuensi Kejadian Giardiasis Asimtomatik

Pada penelitian ini didapatkan frekuensi kejadian giardiasis asimtomatik yaitu sebanyak 14 orang $(22 \%)$. Hasil penelitian ini lebih tinggi dari yang didapatkan oleh Silas dan Hale tentang prevalensi infeksi Giardia lamblia pada anak-anak negara berkembang yaitu berkisar $15-20 \%{ }^{9}$ Prevalensi yang cukup signifikan ini sesuai dengan usia mereka yang rentan dengan infeksi protozoa usus serta kebersihan pribadi murid-murid yang rendah, mempermudah terjadinya infeksi Giardia lamblia. Dibandingkan dengan penelitian terdahulu, hasil ini lebih rendah dengan hasil yang didapatkan oleh Nurhayati pada anak binaan rumah singgah Amanah Kota Padang, didapatkan hasil yang terinfeksi Giardia lamblia sebesar $37,88 \%$ dengan prevalensi infeksi Giardia lamblia sebesar $30 \% .^{8}$ Perbedaan dari penelitian sebelumnya dapat disebabkan beberapa faktor antara lain sanitasi lingkungan, kebersihan perorangan, dan keadaan sosio-ekonomi yang rendah, umur, status gizi, imunitas, dan infeksi parasit usus yang lain. ${ }^{10}$ 
Pada penelitian ini didapatkan bahwa kebiasaan mencuci tangan pada murid SDN 14 Olo $68,3 \%$ adalah baik dan $31,7 \%$ adalah buruk. Hal ini berbeda dari hasil penelitian Dinas Kesehatan Sumatera Barat yang menyatakan bahwa 60,54\% murid-murid SD di Kabupaten Pesisir Selatan mempunyai kebiasaan mencuci tangan yang baik dan $39,46 \%$ adalah buruk. ${ }^{11}$ Penelitian Nurhayati pada anak binaan rumah singgah Amanah Kota Padang, $60 \%$ anak-anak rumah singgah Amanah memiliki kebiasaan sehari-hari yang kurang baik, seperti tidak tidak mencuci tangan sebelum makan. ${ }^{8}$ Perbedaan ini dapat disebabkan karena perbedaan pengetahuan responden tentang kebiasaan mencuci tangan yang baik dan benar, serta perbedaan tingkat kesadaran masyarakat tentang pentingnya kebiasaan mencuci tangan sebelum makan, mencuci tangan sebelum makan jajanan, sesudah bermain tanah dan juga sesudah buang air besar.

Hasil penelitian menunjukkan distribusi frekuensi kebiasaan memotong kuku murid SDN 14 Olo, lebih dari separuh murid memiliki kebiasaan memotong kuku yang baik, yaitu sekitar $58,7 \%$ dan 41,3\% murid memiliki kebiasaan memotong kuku yang buruk. Hal ini berbeda dari hasil penelitian Dinas Kesehatan Sumatera Barat pada murid-murid SD di Kabupaten Pesisir Selatan, dimana hanya sekitar $38,78 \%$ murid mempunyai kebiasaan memotong kuku yang baik. ${ }^{11}$ Perbedaan ini mungkin disebabkan karena perbedaan kebiasaan responden tentang jadwal memotong kuku yang idealnya dilakukan 1 minggu sekali.

\section{Hubungan Kebiasaan Mencuci Tangan dan Memotong Kuku dengan Kejadian Giardiasis Asimtomatik}

Analisis terhadap kebiasaan mencuci tangan dengan kejadian giardiasis asimtomatik, didapatkan bahwa murid yang mempunyai kebiasaan mencuci tangan yang buruk terinfeksi Giardia lamblia lebih tinggi (50\%) dibandingkan dengan murid yang mempunyai kebiasaan mencuci tangan yang baik $(9,3 \%)$. Pada penelitian ini didapatkan hubungan yang bermakna antara kebiasaan mencuci tangan dengan kejadian giardiasis asimtomatik.
Manusia dapat terinfeksi Giardia lamblia dengan menelan kista matang, yang dapat terjadi melalui makanan yang terkontaminasi akibat pengaruh lingkungan dengan higiene yang rendah, serta dapat juga melalui air dan tanah yang mengandung kista Giardia lamblia akibat kontaminasi tinja manusia maupun hewan. Hal ini menyebabkan anak-anak semakin rentan terhadap infeksi Giardia lamblia akibat kebiasaan yang sering bersentuhan dengan tanah, dimana kista ini akan tertelan pada saat anak-anak tersebut makan dan didukung dengan kebiasaan mereka yang tidak mencuci tangan sebelum makan dan sesudah buang air besar. ${ }^{2}$

Keberadaan protozoa intestinal patogen ini tidak selalu menyebabkan sakit pada anak tersebut, namun keberadaannya pada saluran cerna yang nanti dapat keluar bersama tinja, bisa menjadi sumber infeksi bagi orang lain, hal ini didukung dengan higiene pribadi yang rendah seperti mempunyai kebiasaan mencuci tangan yang buruk, baik sebelum makan, makan jajanan, bermain tanah dan setelah buang air besar.

Beberapa penelitian telah membuktikan kebiasaan mencuci tangan berhubungan dengan infeksi Giardia lamblia. Penelitian oleh Anorital dan Dewi didapatkan infeksi Giardia lamblia 11,6\%. Angka kejadian tersebut berhubungan erat dengan kondisi sanitasi lingkungan yang ada belum memenuhi syarat dan kondisi kebersihan perorangan bersangkutan yang belum menerapkan pola hidup bersih dan sehat seperti perilaku tidak mencuci tangan dengan baik dan benar. $^{12}$

Analisis terhadap kebiasaan memotong kuku dengan kejadian giardiasis asimtomatik, didapatkan bahwa murid yang terinfeksi Giardia lamblia lebih banyak pada murid yang mempunyai kebiasaan memotong kuku yang buruk (34,6\%) dibandingkan dengan murid yang mempunyai kebiasaan memotong kuku yang baik $(13,5 \%)$. Namun jika dilihat pada murid yang tidak terinfeksi Giardia lamblia lebih banyak pada murid yang mempunyai kebiasaan memotong kuku yang baik $(86,5 \%)$ dibandingkan dengan yang buruk $(65,4 \%)$. Dapat disimpulkan bahwa tidak ada hubungan yang bermakna antara kebiasaan memotong kuku dengan kejadian giardiasis 
asimtomatik pada murid SDN 14 Olo Kecamatan Padang Barat Kota Padang.

Hasil penelitian ini sejalan dengan penelitian Baidlowi didapatkan bahwa tidak ada hubungan yang bermakna antara kebiasaan memotong kuku dengan kejadian infeksi parasit usus pada anak usia prasekolah di Kedung Cowek, Surabaya dengan nilai $p=0,753(p>0,05) .{ }^{13}$ Berbeda dengan penelitian Rahmawati menunjukkan adanya hubungan terhadap kebersihan perorangan, seperti kebiasaan memotong kuku dan frekuensi memotong kuku. ${ }^{14}$

Perbedaan hasil ini kemungkinan disebabkan oleh sampel yang kurang besar, karena apabila sampel yang diambil lebih besar akan lebih meningkatkan keakuratan dari suatu penelitian, dimana pada penelitian ini sampel yang digunakan sebesar 63 orang. Rancangan penelitian yang digunakan adalah cross sectional, dimana pada observasi kebiasaan memotong kuku responden dilakukan hanya pada satu waktu sehingga memungkinkan responden sudah membersihkan kuku sebelum di observasi, oleh karena itu hasil obervasi belum bisa mewakili keadaan sebenarnya dari responden. Terdapat berbagai faktor resiko selain memelihara kebersihan kuku yang dapat mempengaruhi terjadinya infeksi Giardia lamblia, seperti umur, imunitas, status gizi, higiene perorangan dan lingkungan yang rendah dan infeksi parasit usus lain.

\section{SIMPULAN}

Adanya hubungan antara hubungan kebiasaan mencuci tangan dengan kejadian giardiasis asimtomatik.

Tidak ada hubungan antara hubungan kebiasaan memotong kuku dengan kejadian giardiasis asimtomatik pada Murid SDN 14 Olo Kecamatan Padang Barat Kota Padang.

\section{DAFTAR PUSTAKA}

1. Sutanto I, Ismid SI, Sjarifuddin, PK, Sungkar S. Buku ajar parasitologi kedokteran. Edisi Ke-2. Jakarta: Balai Penerbit Fakultas Kedokteran Universitas Indonesia; 2008. hlm.131-2.
2. Isada C, Kasten B, Goldman M, Gray L, Judith A. Giardia lamblia. Infectious Disease Handbook: Including Antimicrobial Therapy and Diagnostic Test. Edisi ke-5. Ohio: Lexi - Comp's; 2003. hlm. 148.

3. Gillespie S, Pearson R. Principles and practice of clinical parasitology. England: Wiley; 2001. hlm. 225-6.

4. Homan WL, Mank TG. Genotype linked difference in clinically symptomatology. International Journal for Parasitology, Netherlands: Elsevier; 2001. hlm. 822-6.

5. Budiyani L. Infeksi Giardia lamblia pada balita di Kecamatan Jatinegara: Kaitannya dengan status nutrisi. Jakarta: Fakultas Kedokteran Universitas Indonesia; 2009.

6. Herbowo FA. Diare akibat infeksi parasit. Sari Pediatri. 2003;4(4):198-203.

7. Kamilia P. Infeksi blastocystis hominis pada balita di Kecamatan Jatinegara: kaitannya dengan kejadian diare. Jakarta: Fakultas Kedokteran Universitas Indonesia; 2009.

8. Nurhayati. Gambaran infeksi protozoa intestinal pada anak binaan rumah Singgah Amanah Kota Padang. Majalah Kedokteran Andalas. 2010;34 (1):64-6.

9. Silas S, Hale D. Giardia. Lange a medical book: Current diagnosis and treatment in infectious disease, USA: McGraw-Hill; 2001.

10. Loeki E, Aswin B, Nurtjahyo. Protozoa usus patogen yang ditemukan pada anak diare dengan berbagai status gizi. Majalah Kedokteran Unibraw No.3.Vol 12; 1996. hlm. 14-19.

11. Depkes Sumatera Barat. Laporan hasil survei kecacingan pada anak sekolah dasar di Kabupaten Pesisir Selatan; 2002.

12. Anorital, Dewi RM. Distribusi parasit usus protozoa di Kabupaten Hulu Sungai Utara Kalimantan Selatan. Kalimantan Selatan: Badan Litbang Kesehatan; 2010.

13. Baidlowi Al. Hubungan antara higienitis kuku dengan kejadian infeksi parasit usus pada anak usia prasekolah di Kelurahan Kedung Cowek, Kecamatan Bulak, Surabaya. Surabaya: Fakultas Kedokteran Universitas Hang Tuah; 2014. 
14. Rahmawati. Faktor-faktor yang mempengaruh infeksi protozoa usus pada siswa-siswa SD kelas II-IV di SD N Cikeas 02 Kel Cadasngampar
Kecamatan Sukaraja Kabupaten Bogor Jawa Barat 2011. Jakarta: Akademi Perguruan Tinggi $\mathrm{MH}$ Thamrin; 2011. 